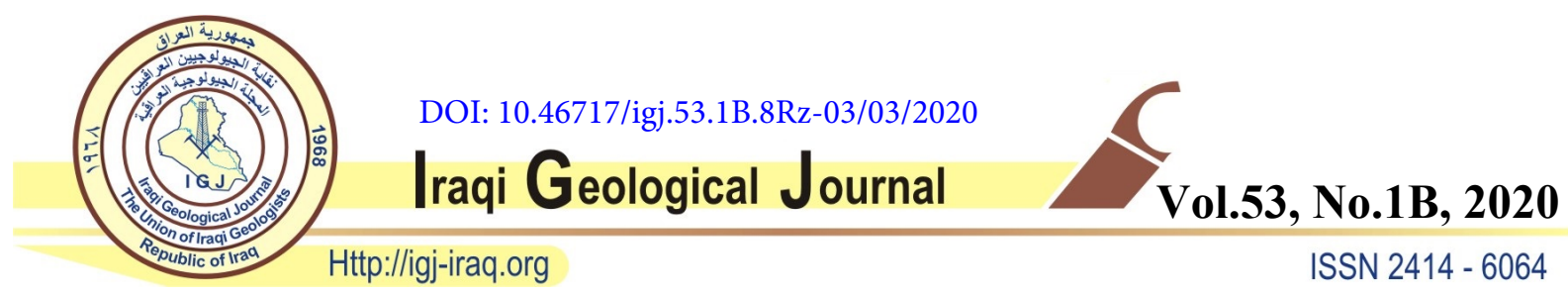

\title{
HIGHLIGHTS ON THE GEOTOURISM IN LIBYAN DESERT
}

\author{
${ }^{1}$ Hwedi Errishi, ${ }^{2}$ Salah, S. El-Ekhfifi ${ }^{*}{ }^{3}$ Ahmed M. Muftah and ${ }^{4}$ Saad O. Elseaiti \\ ${ }^{1}$ Department of Geography, Faculty of Art, University of Benghazi \\ ${ }^{2}$ Exploration Department, National Oil Corporation, Libya \\ ${ }^{3}$ Department of Earth Sciences, Faculty of Science, University of Benghazi \\ ${ }^{4}$ Exploration Division, Arabian Gulf Oil Company, P.O.Box 632, Bengahzi, Libya \\ *E-mail: salahno43@yahoo.com,
}

Received: 23 August 2019; accepted: 31 October 2019

\begin{abstract}
Geotourism of the Libyan desert is highlighted in this paper in terms of its origin and distribution of its elements within the descriptive approach. The Libyan Desert as a part of Great Sahara displays a spectacular Paleozoic geological exposure with unique cultural and social prehistorical panorama in addition to the recent and past volcanism and earthquakes affected areas. The Geotourism features in the studied region can be grouped into two main categories according to their origin: i) internally induced features such as mountain ranges and the associated activities (volcanism and earthquakes affected areas), and ii) externally induced features such as Valleys, dunes, sand sheets, caves, lakes, etc. The Quaternary (Pleistocene Holocene) climatic change impact on the valley terraces and the scattered dry paleolakes are also recorded. Furthermore, the sediments and fossils (faunas and floras) are largely accessible attractive geotourism element in the region. Recent projects of natural resources such as oil and Man-Made River Projects (MMRP) are also considered in this paper for its value.

Keywords: Libyan desert; Geological features; Man-Made river Project; Sustainable geotourism; Fossil wood
\end{abstract}

\section{INTRODUCTION}

The geotourism is defined herein as a kind of tourism where tourists visit the geological and geographical regions for enjoying the fascinating geological features such as Mountain ranges, Plateaus, Valleys (Dry valleys), Karst features, Sand Dunes, Rivers, Lakes (Paleo-lakes) and other attractive geological features which considered an open museum. However, the Travel Industry Association (TIA) of America has defined the geotourism as that type of tourism who focused on the importance of geographical sites and showing the characteristics of the different geological features of the place from the natural, environmental and cultural point of views together with the human activities at that location. The geotourism is also aimed to show the importance of the 
geographical locations to a specific kind of tourists if not all. The natural and human components have been highlighted for tourist's attraction in the Libyan desert, in particular, the southwest of Libya was addressed by Issa, (2003). The geotourism of Al Jabal al Akhdar has been introduced by (Alkowafi, 2004), who linked the geotourist elements into Karstic, tectonic and also tackled the impact of tectonic movement on the archaeological ruins. Some previous works about the geology of the Libyan deserts have been included, among these are Biegi, M. (2002), Rengebach and Le Quellec, (2003), Seilacher, (2000) and (Beuf et al., 1968). Hudman, (1980) pointed that the tourism attraction factors are geographical in its character and considered that the geographical location is the most important factor, where even if all other tourism factors are existing in absence of accessibility, the tourist location becomes irrelevant. The Libyan Desert considered the nearest desert to Europe tourist who are very keen to desert geotourism. Hence the tourists can reach the different tourist localities by plane from Tripoli or Benghazi to Awbari, Sabha or Al Kufra airport to save time to reach and spend more time in visiting and enjoying the concerned exiting and spectacular Geoparks in the middle and far south of the country during driving the 4-wheel vehicles. The desert is characterized by good weather during winter time, so most desert tourist is preferred to organize during this season. The geological desert features play an important role in attracting the tourists due to the followings:

1. They are the corner stone of various past cultural and social communities, who carved, painted and recorded their social and cultural activities during past periods on the walls of the valleys and caves of the mountains, as the prehistoric people used the local rocks in hunting, agriculture and cooking.

2. They displayed various geomorphological features such as plains, dunes, sand sheets, desert arches and rugged hills covered by rocks fragments such as (Al Hamada). All that gave a chance to run different sport and entertainment activities like car Rallies and sand skiing as well as climbing mountains and walking.

3. Desert deposits and associated sedimentary features in addition to fossils and trace fossils, which considered as a historical record that helps in imaging the sort of past life.

4. The weathering features that form the earth's surface by the action of ephemeral running water and winds which is forming an open art gallery as desert arches, caves, natural stacks and others.

5. The different tectonic elements that formed in the mountains in the form of faulting, folding, and joints as well as volcanoes which add a special landscape.

6. The possessing of rare meteorites fields and their relevant features in the impact sites.

The tourist attraction factors are numerous, and their importance varies from person to others. The interplay between ecological, geological and geomorphological pattern in the Libyan desert 
may nominate it to be attractive for many researchers, specialists in these subjects. Libya considered among the countries that willing to invest in perfect all possible tourist resources for the future to replace the completely at the mercy of Oil resources. The sustainable development may define as the best way to circulate the natural resources of the available environment, for instance, the Libyan desert yields valuable tourist resources, the tourism attraction factors comes first the scope of this paper. The protection of past life remains such as fossils and archaeological remains as well, from breakage or unreliable excavation for personnel reasons, which will down grade the importance of these localities by losing these important elements. As much as, the geological attractive features such as caves and the associated archaeological tombs, ancient drawings and other art works, which need protection against uneducated restoration and re-drawings and writing the memories or picking up some archaeological parts. Moreover, the rare and unique remains need special attention, by doing identical replica to simulate these elements and help in displaying them in other Museums (as in case of skulls of invertebrates fossil), as well as organizing a special visits to these sensitive localities such as vertebrate fossil sites (as in As Sahabi area), where 4-wheel drive vehicles are moving across the As Sahabi area, by using other than the known tracks in the area. The archaeological mosaic yards as in (Qasr Libya Museum) needs special attention as well. Conclusively, all these demands should be considered to achieve sustainable tourism, with the rare tourism fragile elements must be displayed in a specialized cabinet in the relevant suite of the Museums. Preserving the natural and archeological heritage from distortion and tampering by the uneducated visitors is in the interest of sustainable development of the geotourism, which in turn aims to serve the desert communities by creating jobs and revitalizing the nature of life and helps officials make the necessary decisions to improve tourism services

\section{MATERIALS AND METHODS}

This work based on information collected from several sources, the most important are:

1. Geological field trip has been conducted by the team work to the different desert localities during different seasons: a trip to Ghat organized by the Exploration division of the Arabian Gulf Oil Company (AGOCo) in the Murzuq Basin and precisely the vicinity of Ghat City in 1985 . Where, fossils, trace fossils samples with photographing of the geological and geomorphological important features has been achieved.

2. Series of geological field trips to As Sahabi area and Jabal Zaltan area in Sirt Basin during the period (1981-2011) organized by the Department of Earth Sciences of University of Benghazi through Garyounis Research Centre. During these field trips, geological maps have been drawn for 
the region, also extensive excavations and surveying have been conducted searching for Pliocene vertebrate fossils.

3. Geological field trips to Al Kufra basin in 1999 conducted by the Austrian Oil company (OMV) to study the geology and tectonism from the features of the exposed rocks where photographing of the geological and geomorphological important features has been achieved.

4. Various short-term geographical field trips pursuing some geological and geographic features in the circumference of Kufra Basin such Awaynat Mountain that have been conducted by the University of Benghazi, Faculty of Art, Department of Geography, Kufra-Branch. Where, fossils, trace fossils samples with photographing of the geological and geomorphological important features have been achieved.

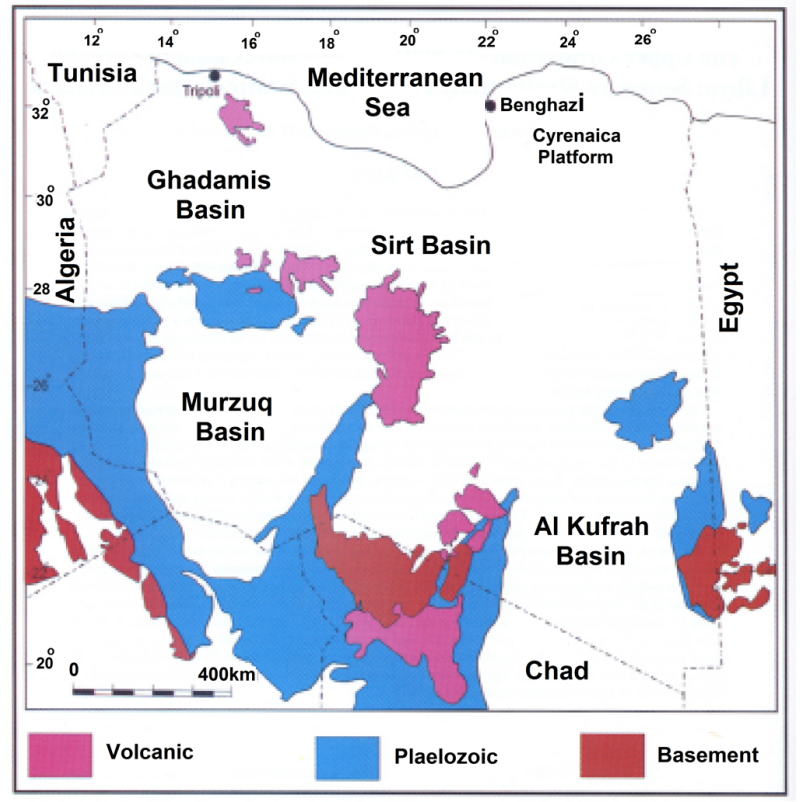

Fig. 1: Map of Libya showing exposed southern exposures

(El Hawat et al., 2003; Thiedig et al., 2000)

RESULTS AND DISCUSSION

Schlüter, (1906) attracted the attention of geographers 1 кeep an eye on what are displayed on the earth's surface of the natural and man-made features which can be sensed and recognized. Therefore, the landscape expresses the natural features, however, the human activities are the most responsible effect on earth's surface than all other creatures, and the effect increased by urbanization and technology advancement (Al Qahtani et al., 1997). Hence, series of changes have been erected (on natural earth surface) where Urlandschaft (i.e. the landscape that existed before the involving the effect of Human activities) transmitted to what is called Kulturlandschaft (i.e. cultural landscape) man-made landscape. 


\section{Natural Landscape}

Brief notes about the documented geological features from the natural landscape are as follows:

\section{Internally Induced Features}

Mountains: There are some mountain chains, Haruj Aswad is a volcano with $1200 \mathrm{~m}$ high and Assawda mountain with 840m high in Sirt Basin; Messak Mountains (Messak Settafet Messak Mellet at Fezzan, in Murzuq Basin, where the Messak is located between Tassili, Tadrart and Acacus mountains; Tibesti mountain with 300m high in southern border of Libya with chad. Isolated hills are also evident in the Kufra Basin (Fig. 5c). The characteristic high pillar (25 m) is a spectacular element for tourists in Murzuq and Kufra basins (Fig. 3C) as well as Desert Arch (Fig. 3D). Paleo-lakes overprinted by sand dunes where many sediments with fossils and Ancient man remains along their beaches back to Neolithic age (Rengebach and Le Quellec, 2003) (Fig. 2).

Volcanoes: Waw an Namus is a volcano (Fig. 3E) associated with the Al Haruj al Aswad mountain, it characterized by its conical shape with circular crater dated Recent time. It surrounded by three lakes with different sizes, with underground recharge due to the shallow aquifer. This attractive place received many tourists as it considered an attractive site for a long time (Figs. 2 \& 3 ). However, Tibesti witnessed volcanic activity during the latest Cenozoic era (Tertiary period) which led to extensive erosion of the conical volcanoes, however, the second volcanic activity appeared in Quaternary time, however, dike hills are also seen in Sirt Basin close to Al Haruj (Fig. 2).

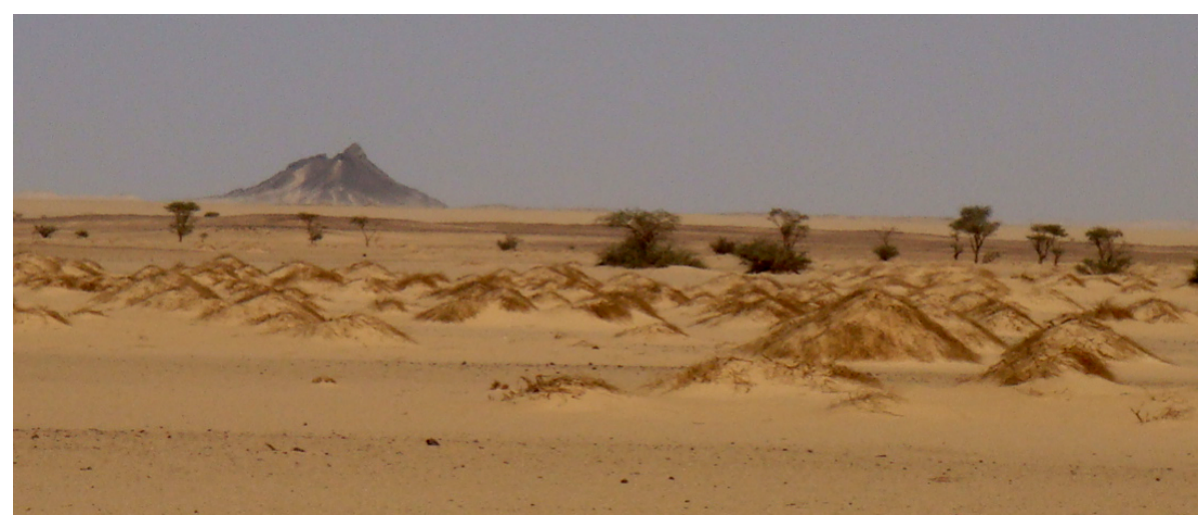

Fig. 2: A unique dike hill is raised in the plain with dried shrubs (hillocks). Acacia trees also scattered

Earthquake affected areas: The desert as well as coastal areas of Libya hit by a series of earthquakes in different times, which caused huge destruction to many pre-historic heritage. Two examples of the destructed cities by the earthquakes are:

1. Aqadir city in Algeria hit by an earthquake in 1960 and the new city was rebuilt $1.6 \mathrm{~km}$ further south from the old city. 
2. Marj city in Cyrenaica, Northeast Libya hit by an earthquake on 21 February 1963 and the new city rebuilding was undertaken about $5 \mathrm{~km}$ further west from the old city. Both are attractive to special tourists to see the effect of destruction. The youngest earthquake was that in 1936 which destroy all the archaeological works in Wadi Garza area, the tributary of Wadi Zamzam (General Tourist Association, Tripoli). The previous studies about earthquakes ended with limited information from some places such as that earthquack that struck Murzuq city in 1853 and Ghadamis city in 1883 as an example but not least (Ambraseys, 1994) due to absence of modern earthquake recorded instruments.

\section{Externally Induced Features}

Valley: This geomorphological alluvial features are very characteristic in the Libyan desert, where, during rainfalls produces flooding to erode the weathered rocks, and give a chance to the seasonal Acacia (Fig. 2) and other small desert plants to grow as in the case of deep Wadi Tin Hamotin in Messak Settafet high (Fig. 3G). Drainage pattern: The desert area received seasonal rainfalls from time to time which are responsible forf dendritic drainage patterns (Figs. 3F, 5h).

Sand dunes: The intermittent high speed winds blowing on the Libyan desert transporting the sand sediments, during this action the moving sands carve the facing mountain leaving behind a fantastic natural art work as observed in Tibesti and Awaynat mountains (Fig. 3A, 5d). Additionally, the winds are responsible for the deposition of these eroded sands in the various sedimentary basins. Although, the winds may fade away the man-made painting art work that drawn by the ancient man who inhabitant the area as seen in Tassili and Acacus rock surfaces (Figs. 3H, 5f), this issue drives the concerned people to protect this worldwide heritage. The surrounding areas of Awbari and Sabha are unique in accommodating sand dunes of Longitudinal (Sief), Barchans and irregular types. They are commonly associated with other primary sedimentary structures such as cross beddings (Fig. 5a), or secondary sedimentary structures as ripple marks (Fig. 5b) and Root casts and other trace fossils.

Sand sheets: They occupy an enormous area of the Libyan desert, which in many occasions invested to run some sporting activities (Rallies) the great sand sea which extends up to $250 \mathrm{~km}$ and Idhan Murzuq etc... (Fig. 3B).

Natural Lakes: The lakes in the dry area as deserts usually play important role for the animals and birds during their migration, the water could be sweet or salty as in Qabar Oun lake in Sabha and Al Fraidgha lake in Jaghbub, as well as the three lakes, surrounded the Waw An Namus volcano (Fig. $3 \mathrm{E})$. 


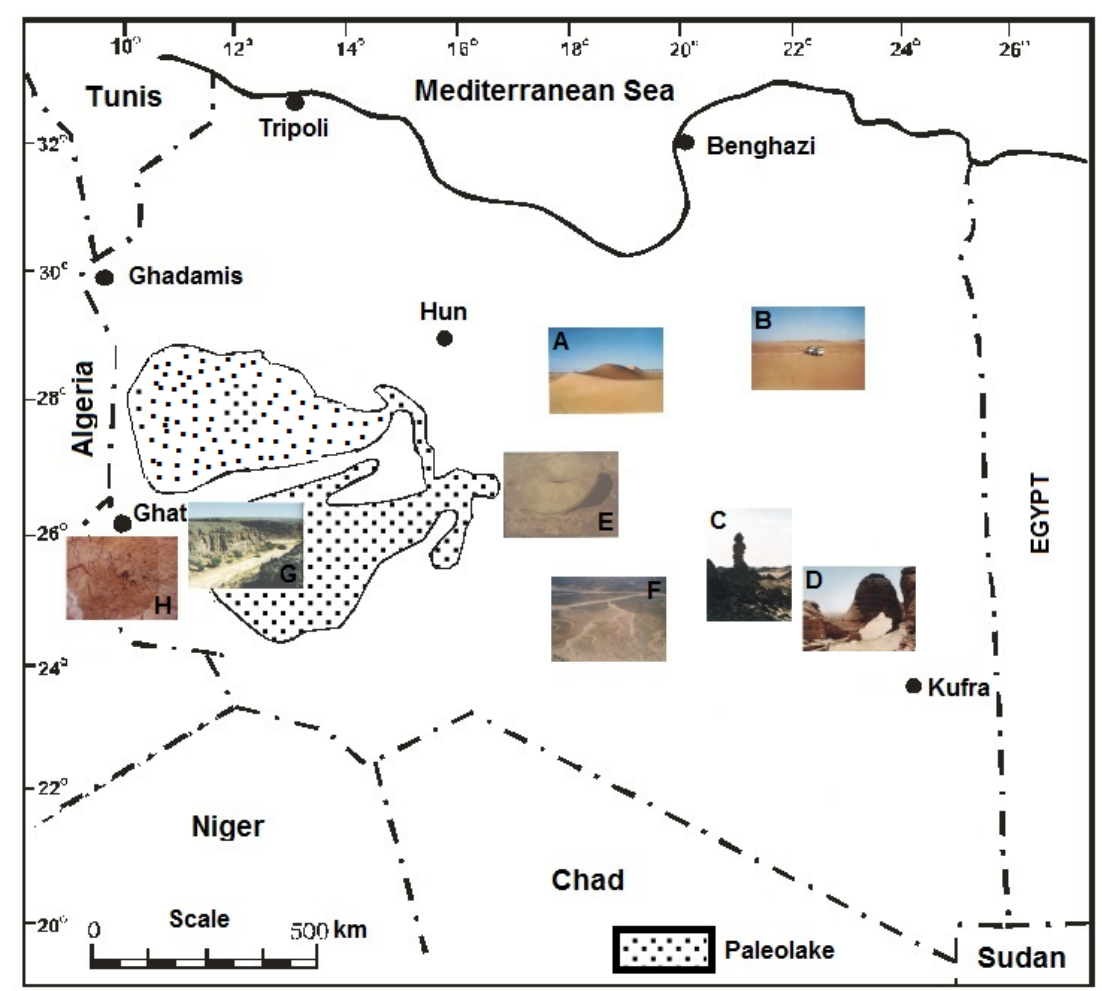

Fig. 3: Map shows some geotourism localities in the Libyan desert and Fezzan paleolake. (A: sand dunes; B: sand sheet; C: high pillar; D: desert arch; E: Waw an Namus volcano; F: drainage pattern; G: dry valley; $H$ : ancient paint drawings)

\section{Miscellaneous Geological Features}

Fossils: They are remains of past animals and plants (fossils) or their activity traces (trace fossils). They are preserved in rare scattered places in the Libyan desert in different forms, Presence of marine fossils in the upper mountain's exposures indicating that they are originally deposited in the marine environment which followed by tectonic forces ended with uplifting the area. On the other hand, fossils not found in igneous rocks, however, in metamorphic rocks of sedimentary origin may present but in destroyed forms to be identified. Generally, in the Libyan desert the trace fossils (Burrows, Borings) are more dominant than macrofossils (Graptolites, Brachiopods, Trilobites, and Fossil wood). Some of the documented fossils are Trilobites and Graptolites which indicating Silurian age as in Tanezzuft Formation (Fig. 4f and 4h). Petrified wood which presents in As Sahabi area (Fig. 4i) and Southwest of Sabha along the Ubari highway as well as in Southwest of Kufra. Gypsified Mollusks, Clypeaster-echinoides (Fig. 4e) and Corals also commonly preserved in As Sahabi area and west of Maradah area. Stromatolites, the remains of blue green algae in Paleozoic rocks as reported in Murzuq Basin (Fig. 4g).

Trace fossils on the other hand which considered as the casts and prints of ancient animals or plants that prevailed in the past environments are easily recognized as they protruding from hosting 
rocks due to the contrast in the pattern of the depositional phases. Trace fossils are numerous and diverse, so used in local and regional stratigraphic correlations. The trace fossils look like an art work by a specialist. The documented ichnofossils are:

1. Crawling traces in form of Arthrophycus and Cruziana (Fig. 4d) and Harlania in Lower Acacus rocks of Murzuq Basin (Seilacher, 2000) (Fig. 4c).

2. Grazing traces in form of Zoophycus (Fig. 4b).

3. Dwelling traces in form of Tigillites in Houaz Formation, Murzuq Basin, Ophiomorpha as in As Sahabi area (Fig. 5e).

Also, the wood fossils present in As Sahabi as an open petrified forest Museum. As Sahabi area is a place where the vertebrate remains (bones, teeth, skulls) are commonly exhibited by the natural weathering process by action of wind alone. Therefore, all visitors are not allowed to take any vertebral bone fragment for its fragility and breakage during collection. This, in turn will hide a lot of the scientific information of the place containing it.

However, the abundant invertebrate fossils such as Echinoids (Fig. 4e) and Molluskan shells can be collected and obtained without restriction. Additionally, some rose gypsum in As Sahabi area also decorating younger Pliocene beds (Fig. 5a).

Mineral resources: Some sites of the Libyan desert yielded ore materials as that iron deposits near Wadi Ashati and salt deposits in Subkha such as Subkhat Al Quzzial and Sabkhat al Qunayyin and Subkhat Murzuq. Also, iron concretions which are iron oxides deposits found in sedimentary rocks of spherical-oval shaped due to aqueous environments such exposed in Murzuq Basin (Fig. 5g). Among the most recent published studies searching for minerals are Shaltami et al., (2018a) in relation to Uranium and Shaltami et al., (2018b) in relation to iron ores.

Meteorites evidences: There are rare evidences of meteorites rocks and associated circular structures, where two circular depressions close to Cufra (about $50 \mathrm{~km}$ east of Cufra) with diameter approaching 12km, however, the second one in Qarat Al Ibrah (about 85km North of the first one) both considered among the famous tourist targets (Beigi, 2002). Other scientific reconnaissance pointed out that there is a meteorite field in Dar Al Ghani South Al Hamada al Hamrah Abu Aghreb et al., (2003).

Precambrian rocks: The Precambrian exposed rocks considered a valuable scientific era due to its rare exposures worldwide, particularly, in Libta it covers only 1\% of the area of Libya, in Eghei, Awaynat, Tibesti mountains (Fig. 1). They comprise a folded metamorphic rocks of clastic sedimentary origin cross cut by igneous granitic rocks of Precambrian age (Klitzsch, 1963). 

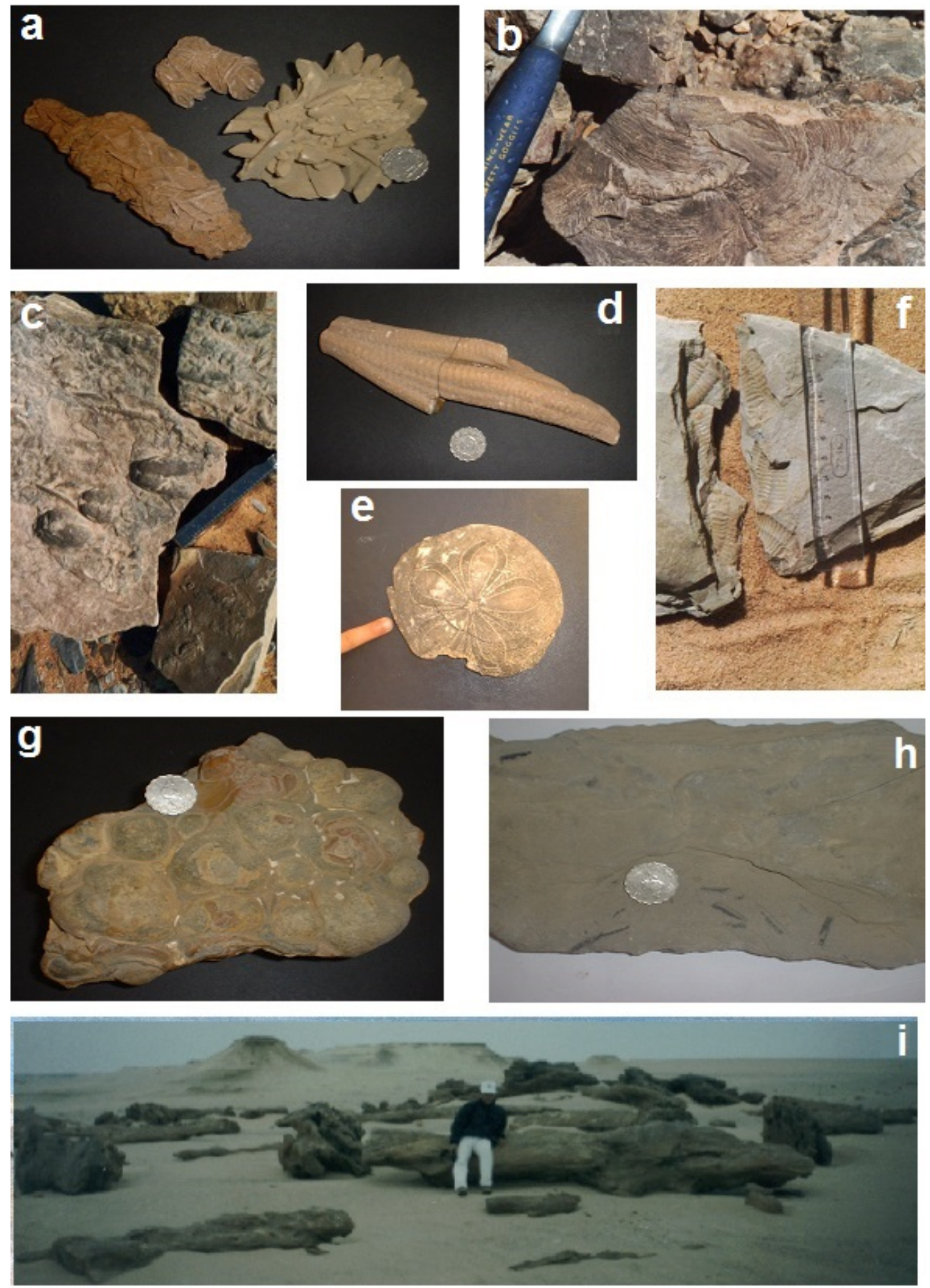

Fig. 4: a) Rose Gypsum from As Sahabi area; b) Spirophyton traces Kufra Basin; c)

Cruziana type-II, Silurian, Kufra Basin; d) Arthrophycus Acacus Sandstone, Murzuq Basin; e) Clypeaster sp. from As Sahabi area; f) Trilobites molds from Tanezzuft Shale, Kufra Basin; g) Stromatolites- blue green algae from Murzuq Basin; h) Graptolites from Silurian Tanezzuft, Murzuq Basin; i) wood fossils in As Sahabi area 

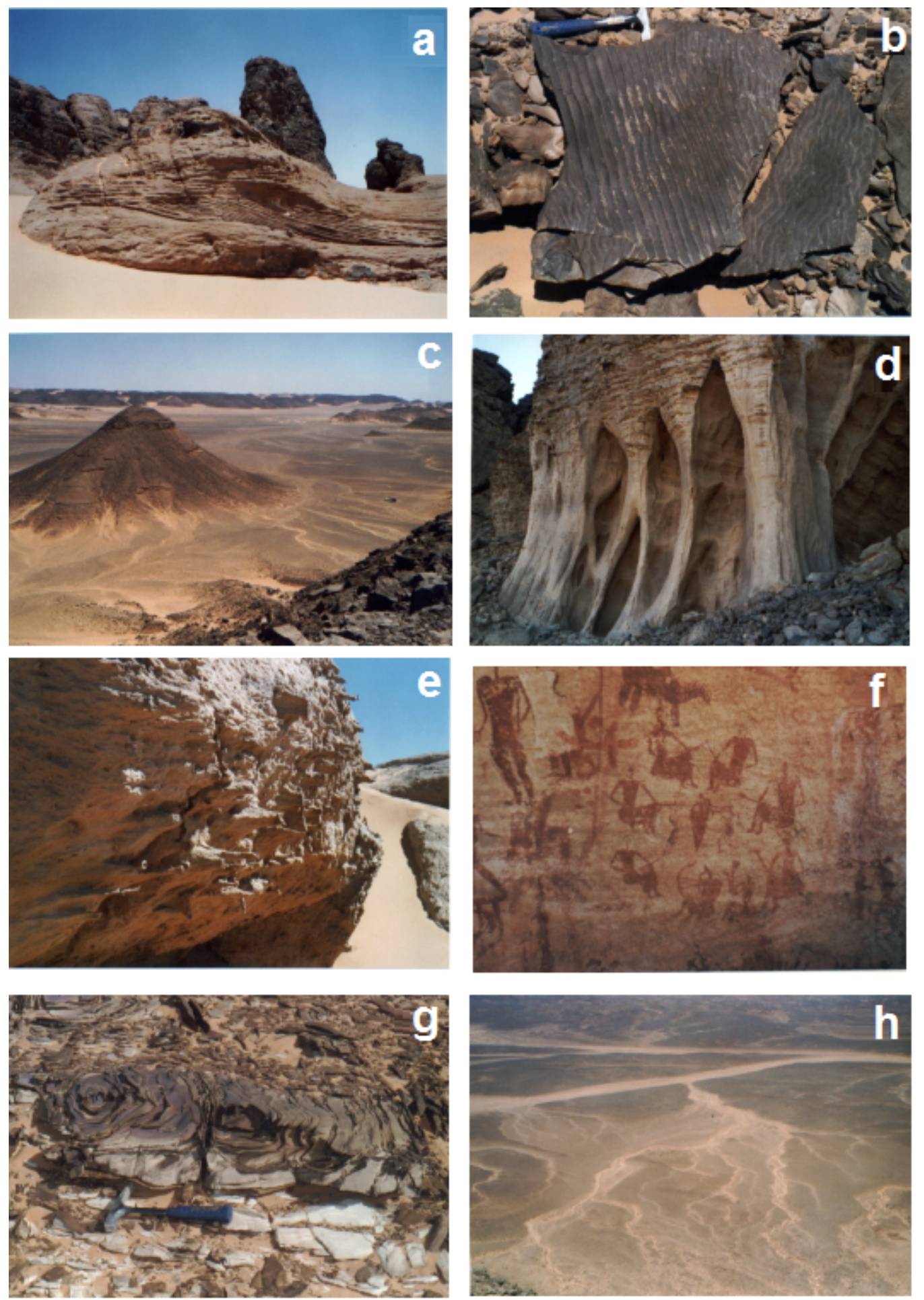

Fig. 5: a) Cross-bedding exposed in Kufra Basin; b) Ripple marks exposed in Kufra Basin; c) Isolated hill, (note: faulting and drainage pattern) Kufra Basin; d) Wind carving in Kufra Basin; e) Horizontal burrowing protruding via wind erosion, Kufra Basin; f) Ancient drawing shows group of women singing party, mountains near Ghat, Murzuq basin; g) Iron concretion, showing the thermal expansion physical weathering, Murzuq Basin; $h$ ) seasonal dendritic drainage patterns in Kufra Basin 
Paleozoic climatic change (Ordovician Period): There are different signatures in the desert areas helping in stimulating the paleoclimate as in the dry and wet seasons. Martin, (2010) pointed out the importance of the glacier dynamic and landforms in his tourist project related to the TsanfleuronSanetsch area in Valais, Switzerland. In Libyan desert, the Paleozoic glacier period ( $>428$ m. a.) displayed glacial striations on the upper exposed surface of Mamuniat Formation, Ghat area in Murzuq Basin (Fig. 6), this dynamic glacial sign was formed due to interplay between the glacial bed load with the floor of the glacial valley during Ordovician, this is also reported along the Hoggar mountain range (Beuf et al., 1968).

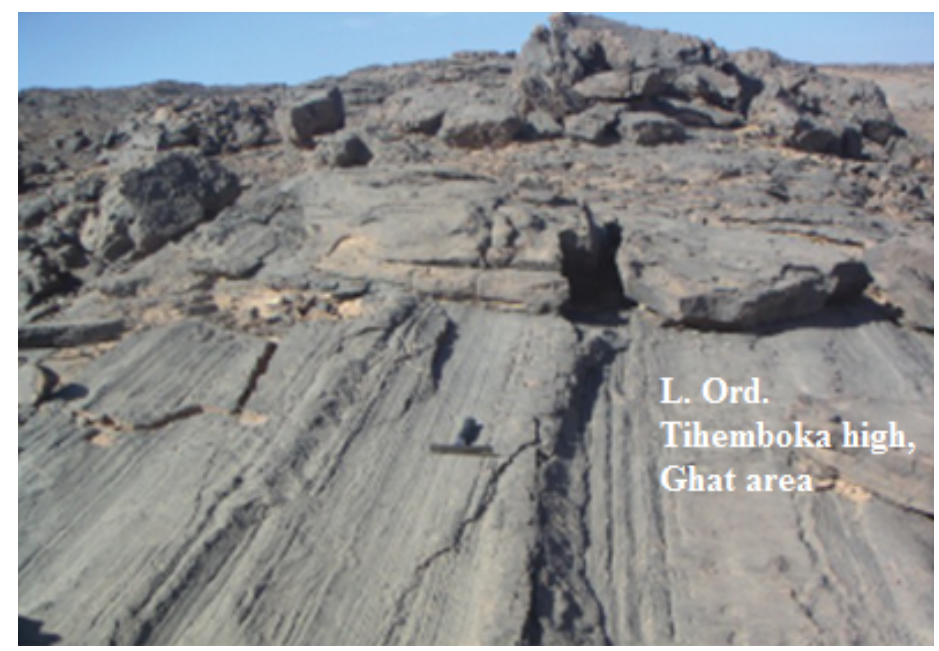

Fig. 6: Glacial striations on the surface of Mamuniat Formation in Ghat, Murzuq Basin

Quaternary climatic change (Pleistocene-Holocene): There are many evidences to raining seasons in the middle and low latitudinal area corresponding to the glacial phases of high latitudinal area, among these, paleosoils, dry valleys (Figs. 2, 3G, F) and dry paleolakes (Fig. 3).

Plaeosoils: The area preserved as layers of soils containing variable Organic matter with plant roots in some areas, reflecting the enhancement of the climatic conditions by receiving good rains.

Deposits of paleolakes: They are representing by lake sediments containing fossils reflecting climatic and environmental indication, the most famous one is Fezzan paleolake (El Hawat et al., 2003; Tiedig et al., 2000) (Fig. 3).

Dry valleys: They are many dry valleys in the Libyan desert, which indicating to periods of huge flowing running water during Pleistocene and early Holocene (Figs. 3G, 5h).

\section{Cultural Landscape}

There are several sites of man painting or engraving works on the cave or on valleys sides, which are documented in the sporadic archaeological sites as in Wadi Tin Hamotin in Messak Settafet high as example but not least, some other architecture art as that used in construction of Ghat and 
Ghadamis cities as well as the drawings art expressing the folkloric, songs and dancing (Figs. $3 \mathrm{H}$, $5 f)$.

Man-Made River Project: This great project is the gigantic project in the field of civil engineering which performed by 5 phases, two fundamental phase and three completion phases. A subterraneous fresh water river flew via super pipes of 4-meter diameter crossing the desert to feed coastal cities with a total distance reached $4000 \mathrm{~km}$. The tourist can visit the water reservoirs as in Ajdabiya city and the site of manufacturing of the pipes and the employee's camps in the desert as in Tazerbo for example, all these are attractive elements as well. Since these are strategic sites, it is preferable to organize tourist group visits through specialized tourist agencies.

\section{CONCLUSIONS}

The Libyan desert yields various economical resources such as oil and gas, minerals and Geotourist sites. This paper introduces the components of the desert geotourist elements which can't be founded solely, therefore it should be established in association with other types of tourisms (cultural and archaeological).

Highlighting the geological attractive features that distributed in the Libyan desert, for example, the glacial striations, meteorites, paleolakes, subkhas, mineral deposits and fossils. Introducing some of the tourist elements of the Libyan desert of its paleoenvironments such as the As Sahabi, Dur al Talha and Jabal Zaltan area via the studied vertebrate bones and teeth remains.

\section{RECOMMENDATION}

This study to advertise and market this type of tourism (Geotourism) to support the archaeological and desert tourism.

Buildup the infrastructure for support this type of Tourism such transportation (Planes, cars and trains if necessary) as well as hostels or permanent residential camps for accommodations.

Applying laws related to the protection of rare scientific tourist areas as a world heritage as in As Sahabi, Dur al Talha and Jabal Zaltan areas.

\section{ACKNOWLEDGEMENTS}

We would like to thank Dr. S. Sofialdeen, Dr. M. Al-Babopor for their valuable discussions, Our gratitude extended to Mr. K. Ashahomi, Dr. A, El-Mehdawi, Mr. A. Fazzani, and Dr. S. Al Gaziri for their help to produce this paper.

\section{REFERENCES}

Abu Aghreb, A.E, Ghadi, A. M., Schlüter, J., Schultz, L., and Thiedig F., 2003. Hamadah Al Hamra and Dar Al Gani: A comparison of two meteorites fields in the Libyan Sahara (Abstract no. 40). Meteoritics \& Planetary Science 38, Nr 7, Supplement, A9 A153.

Al Qahtani, M., Arbab, M., and Abdul Monem A. L. 1997. Tourism, Principles and concepts: An Empirical Study of Asir Region, Saudi Arabia. Al Madinah Press. (Dar Al Elm) Jeddah. (in Arabic). 
Al Kowafi, A.M., 2004. Geotourism in Al Jabal al Akhdar, Libya. The Arabic culture Magazine, 258: 64-72. (in Arabic).

Ambraseys, N.N., 1994. Material for the investigation of the seismisity of Libya. In: Reynolds (ed.), Cyrenaican Archaeology: International Colloquium, Libyan studies, 25: 7-22.

Beuf, S., Biju-Duval, B., Stevaux, J., and Kulbicki, G., 1968. Extent of (Silurian) glaciation in the Sahara: Its influence and consequences upon sedimentation. Petrl. Explor. Soc., Libya, 11th ann. Field conf. (1969) In: W. H. Kane (ed.), Geology, Archaeology and prehistory of Southwestern Fezzan, Libya, 103-116.

Biegi, M., 2002. Libyan meteorite impact craters: The geological and economic importance. (Abstract) (in Arabic).

El-Hawat A.S., Bezan, A., Obeidi, A. and Bargathi, H., 2003. The Upper Ordovician-Lower Silurian succession of Western Libya: Sequence Stratigraphy and Glacioeustatic-Tectonic Scenario. In: M.J. Salem and K. Oun (eds.), The Geology of Northwest Libya ESSL. Tripoli, 65-78.

Hudman, L.E., 1980. Tourism: A shrinking world. Annals of tourism research, 9 (2):284-286

Issa, M.A., 2003. Was the Sahara the first home of art and writing before Nile Valley? International scientific conference on natural resources and culture heritages, Tripoli. (in Arabic).

Klitzsch, E., 1963. Geology of the North-East flank of the Murzuk basin (Djebel Ben Ghnema-Dor el Gussa area). Rev. Inst. Fr. Petrole, Paris, 18(10-11):1411-1427.

Martin, S., 2010. Geoheritage popularisation and cartographic visualisation in the Tsanfleuron-Sanetsch area (Valais, Switzerland). In: Regolini-Bissig G., Reynard E. (eds.), Mapping Geoheritage, Lausanne, Institut de géographie, Géovisions, 35:15-30.

Rengebach, J-C. and Le Quellec, J.C., 2003. Saharan Heritage and Seismic Acquisition. Total E \& P Libye, 128pp.

Seilacher, A., 2000. Ordovician and Silurian Arthrophycid Ichnostratigraphy. In: M.A. Sola and D. Worsley (eds.), Geological Exploration in Murzuq Basin. Elsevier, Amsterdam, 237-258.

Schlüter, O., 1906. Die Ziele der Geographie des Menschen. Munich and Berlin: Oldenbourg.

Shaltami, O.R., Fares, F.F., El-Oshebi, F.M., Errishi, H., Bustany, I., 2018a. Uranium Minerals Hosted in the Zarzaitine Formation at Tahughatin area, SW Libya. 5th International Conference on Engineering and Applied Sciences, Prague, Czech Republic, 113-121.

Shaltami, O.R, Fiannacca, P., Fares, F.F., El-Oshebi, Siasia, G.D., and F.M., Errishi, H., 2018b. Geochemistry of iron ore at Wadi shati, SW Libya: Implications on origin, depositional environment, paleooxygenation, paleoclimate and age. 14 ${ }^{\text {th }}$ Biennial Meeting of Society for Geography Applied to Mineral Deposit, Quebec Canada:37-50.

Thiedig, F., Oezen, D., El-Chair, M., and Geyh, M.A., 2000. The absolute age of the Quaternary lacustrine limestone of the Al Mahruqah Formation-Murzuq Basin, Libya. In: M.A. Sola and D. Worsley (eds.), Geological Exploration in Murzuq Basin, Elsevier, Amsterdam., 89-116. 